\title{
In vitro evidence for the antibacterial role of lysozyme in salmonid eggs
}

\author{
A. N. Yousif ${ }^{1}$, L. J. Albright ${ }^{1}$, T. P. T. Evelyn ${ }^{2}$ \\ ${ }^{1}$ Institute for Aquaculture Research, Department of Biological Sciences, Simon Fraser University, Burnaby, British Columbia, \\ Canada V5A 1S6 \\ ${ }^{2}$ Department of Fisheries and Oceans, Pacific Biological Station, Nanaimo, British Columbia, Canada V9R 5K6
}

\begin{abstract}
The yolk material of coho salmon Oncorhynchus kisutch eggs contains at least 1 naturally occurring antibacterial factor - lysozyme. The antibacterial properties of this lysozyme were studied with selected bacterial fish pathogens. It was found to be rapidly bactericidal to Aeromonas hydrophila, Aeromonas salmonicida, and Carnobacterium piscicola at a concentration of $700 \mathrm{\mu g} \mathrm{ml}^{-1}$, a concentration approximately one-third of that found in the yolk of most salmonid eggs. However, the lysis that it caused with the test bacterium Micrococcus lysodeikticus did not occur with the foregoing fish pathogens. The kidney disease bacterium Renibacterium salmoninarum was not killed when incubated with as much as $1900 \mu \mathrm{g} \mathrm{ml}^{-1}$ of the enzyme for $90 \mathrm{~min}$. The data presented indicate that the antibacterial role of lysozyme should not be equated merely with its ability to lyse microorganisms, and that lysozyme has a role in preventing the mother to progeny (vertical) transmission of some bacterial fish pathogens. Its failure to kill $R$. salmoninarum helps to explain why this organism is readily vertically transmitted.
\end{abstract}

KEY WORDS: Lysozyme $\cdot$ Salmonids $\cdot$ Eggs $\cdot$ Pathogens $\cdot$ Vertical transmission

\section{INTRODUCTION}

Natural antimicrobial humoral factors in fish have been described (Ingram 1980, Fletcher 1982). One of the best-known of these antimicrobial substances is lysozyme, an enzyme that hydrolyses the bacterial cell wall mucopeptide $\mathrm{N}$-acetylmuramic acid-N-acetylglucosamine linkage. This enzyme is ubiquitous in the living world and has been reported to occur in the kidney and digestive tissues of rainbow trout Oncorhynchus mykiss (Lindsay 1986, Grinde et al. 1988, Grinde 1989), in the kidney tissues of Atlantic salmon Salmo salar (Lie et al. 1989), and in the eggs of several salmonid fish (Yousif et al. 1991).

The bacterium Renibacterium salmoninarum responsible for bacterial kidney disease (BKD) is transmitted from mother to progeny via the egg (vertically transmitted). Cells of the bacterium can apparently enter the egg prior to ovulation (Lee \& Evelyn 1989) or through the micropyle after ovulation, while the egg is in contact with infected coelomic fluid (Evelyn et al. 1984a). Other Gram-positive and Gram-negative bacteria that are small enough to pass through the micropylar canal, including the fish pathogens Aeromonas hydrophila, A. salmonicida, and Carnobacterium piscicola (Collins et al. 1990) (formerly Lactobacillus piscicola; Hiu et al. 1984), also occur in the coelomic fluid of spawning fish (Cone 1982, Evelyn et al. 1984a, b, Sauter et al. 1987. Barker et al. 1989). These bacteria are thus in a position to enter the eggs yet, unlike $R$. salmoninarum, they appear not to be vertically transmitted.

The present study was undertaken to evaluate the role of coho egg lysozyme as an antibacterial factor against bacteria that are often found in coelomic fluid of spawning salmonids. Our goal was to determine whether susceptibility to the enzyme could explain why some bacteria are vertically transmitted and some are not.

\section{MATERIALS AND METHODS}

Lysozyme. Coho egg lysozyme was purified as described in Yousif et al. (1991), and dissolved in $0.06 \mathrm{M}$ phosphate buffer at pH 6.0 containing $0.02 \mathrm{M} \mathrm{NaCl}$ 
(PBS). The enzyme was filter-sterilized $(0.22 \mu \mathrm{m}$ pore size Nuclepore filter), and stored at $4{ }^{\circ} \mathrm{C}$. The concentration of the enzyme in the preparations $(100,400$, $700 \mu \mathrm{g} \mathrm{mI}^{-1}$ ) was determined by the lysoplate method described by McHenery et al. (1979). Briefly, $20 \mu \mathrm{l}$ aliquots of sample were dispensed into wells $(3.5 \mathrm{~mm}$ in diameter $\times 4 \mathrm{~mm}$ deep) cut into $0.5 \%$ agarose (Type 1, Sigma) in $15 \mathrm{~cm}$ diameter Petri dishes. The agarose contained PBS and Micrococcus lysodeikticus (0.6 $\mathrm{mg} \mathrm{ml}^{-1}$ freeze-dried, viable cells, Sigma). After incubation for $20 \mathrm{~h}$ at room temperature in a humid chamber, the diameters of zones of $M$. lysodeikticus lysis were measured and compared to those produced by various known concentrations of hen egg-white lysozyme (HEWL, Sigma).

Bacteria and growith conditions. The origins of the bacterial strains were as follows: Aeromonas salmonicida (strain \#76-30), the causative agent of furunculosis, and Renibacterium salmoninarum (strain \#384) were isolated from juvenile salmon at the Department of Fisheries and Oceans (DFO) Quinsam River Hatchery, Vancouver Island, B.C., Canada, in 1976 and 1979, respectively. A. hydrophila (strain \#35), known to cause a hemorrhagic septicemia in saimonids, was isolated from an adult pink salmon Oncorhynchus gorbuscha at the Robertson Creek Hatchery, B.C. in 1965. These bacteria possessed the external proteins normally associated with virulence: the A-layer protein (A. salmonicida), the p57 protein ( $R$. salmoninarum), and the S-layer protein (A. hydrophila). Camobacterium piscicola (strain \#B270), a Gram-positive coccobacillus that causes pseudokidney disease in salmonids, was a generous gift of Dr J. Fryer (Oregon State University, Corvallis, OR, USA). To increase the range of salmonid-associated bacterial taxa included in this study, bacteria were also isolated from the coelomic fluid of a single brood coho salmon female. Identification of isolated bacteria was done using standard microbiological methods and by reference to Krieg \& Holt (1984) and Sneath et al. (1986). Two types of bacteria were isolated (Table 1). One of these resembled Flavobacterium (Gram-negative, nonmotile rods, aerobic, oxidase- and catalase-positive), while 2 other closely related bacteria were identified as members of the genus Corynebacterium (Gram-positive irregularly stained rods, non-motile, facultatively anaerobic, oxidase-negative and catalase-positive). Stock cultures of all bacteria were kept at $-70^{\circ} \mathrm{C}$ in tryptic soy broth (TSB, Difco, Detroit, MI), or in KDM-2 broth (Evelyn 1977). Both media were supplemented with $1 \%$ gelatin. Propagation of all bacteria except $R$. salmoninarum was carried out using brain heart infusion $(\mathrm{BHI}$, Difco) agar at $15^{\circ} \mathrm{C}$. R. salmoninarum was grown on a charcoal agar medium (Daly \& Stevenson 1985) that had been made selective (SKDM-C) for the bacterium by the addition of antibiotics described by Austin et al. (1983).
Table 1. Biochemical characteristics of 3 bacterial isolates from the coelomic fluid of a female brood coho salmon Oncorhynchus kisutch in British Columbia, Canada. TSA: tryptic soy agar; $\mathrm{O}$ : oxidative

\begin{tabular}{|c|c|c|c|}
\hline Characteristic & $\begin{array}{l}\text { Flavobac- } \\
\text { terium sp. }\end{array}$ & $\begin{array}{l}\text { Corynebac- } \\
\text { terium sp. }\end{array}$ & $\begin{array}{c}\text { Corynebac- } \\
\text { terium } \mathrm{sp} \text {. }\end{array}$ \\
\hline Gram reaction & - & + & + \\
\hline Motility & - & - & - \\
\hline Morphology & rod & rod & rod \\
\hline \multicolumn{4}{|l|}{ Production of yellow } \\
\hline Endospore & - & - & - \\
\hline Acid-fast & - & - & - \\
\hline Growth at $37^{\circ} \mathrm{C}$ & - & - & - \\
\hline \multicolumn{4}{|l|}{ Growth on TSA } \\
\hline$+7.5 \% \mathrm{NaCl}$ & - & - & - \\
\hline Growth on nutrient agar & $a r+$ & + & + \\
\hline $\begin{array}{l}\text { Growth at room temp. } \\
\left(18 \text { to } 22^{\circ} \mathrm{C}\right)\end{array}$ & 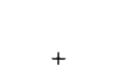 & + & + \\
\hline \multicolumn{4}{|l|}{ Hydrolysis of: } \\
\hline Gelatin & + & + & + \\
\hline Agar & - & - & - \\
\hline \multicolumn{4}{|l|}{ Acid from: } \\
\hline Glucose & + & + & - \\
\hline Sucrose & + & - & - \\
\hline Lactose & - & - & - \\
\hline Methyl red & - & - & - \\
\hline Simmons citrate & - & + & + \\
\hline Indole production & - & -- & - \\
\hline $\mathrm{H}_{2} \mathrm{~S}$ production & - & - & - \\
\hline Urease & - & - & + \\
\hline Nitrate reduction & - & + & + \\
\hline Catalase & + & + & + \\
\hline Oxidase & + & - & - \\
\hline \multicolumn{4}{|l|}{ Growth on } \\
\hline MacConkey agar & - & - & - \\
\hline Voges-Proskaur & - & - & - \\
\hline Oxidative-fermentative & 0 & $\mathrm{O}$ & $\mathrm{O}$ \\
\hline
\end{tabular}

Antibacterial activity determination.

Bactericidal assay: The effect of lysozyme on the viability of the bacterial fish pathogens (Aeromonas hydrophila, A. salmonicida, Camobacterium piscicola, and Renibacterium salmoninarum) was investigated. Log-phase bacterial cultures were aseptically scraped off agar plates and suspended in sterile PBS. The cells were washed twice by centrifugation $(5860 \times g$ for 15 min at $4^{\circ} \mathrm{C}$ ) in PBS, and the final suspension was adjusted to an approximate absorbance of 1.0 at $540 \mathrm{~nm}$. Samples $(1.0 \mathrm{ml})$ of each suspension were then dispensed into Eppendorf tubes and centrifuged (Micro-Centrifuge, Model 235C, Fisher Scientific) for 10 min at room temperature. The supernatants were discarded and the bacterial pellets were resuspended for $90 \mathrm{~min}$ in $1.0 \mathrm{ml}$ aliquots of the enzyme preparations $\left(100,400,700 \mu \mathrm{g} \mathrm{m} \mathrm{m}^{-1}\right)$ at room temperature. Samples (in triplicate) were taken from each suspension and diluted 10-fold in Eppendorf tubes containing 
sterile peptone $0.1 \% /$ saline $0.85 \%$. The bacterial suspensions were sampled at the start of the experiment (time $=0$ ) to determine colony-forming units (CFU) $\mathrm{ml}^{-1}$ used in the experiment. Sampling was also done every $30 \mathrm{~min}$ to determine the effect on CFU brought about by the enzyme. These dilutions were then dropinoculated $\left(25 \mu \mathrm{l} \mathrm{drop}^{-1}\right)$ on the appropriate agar media, and colonies that developed were enumerated after a period of incubation at $15^{\circ} \mathrm{C}$. A. hydrophila, $A$. salmonicida, and $C$. piscicola were incubated on tryptic soy agar (TSA, Difco) for $48 \mathrm{~h}$ before counting. $R$, salmoninarum, however, was drop-inoculated on SKDM-C supplemented with a 'nurse' culture as described by Evelyn et al. (1989), and colonies were counted after 4 to $6 \mathrm{wk}$ of incubation at $15^{\circ} \mathrm{C}$. The bactericidal effect of lysozyme was inferred from the difference between CFU in the control suspensions (bacteria incubated in PBS) and the enzyme-containing suspensions (bacteria incubated in different concentrations of lysozyme).

The susceptibility of Aeromonas hydrophila, A. salmonicida, and Carnobacterium piscicola to lysozyme was also studied at a low incubation temperature by addition of $25 \mu \mathrm{l}$ of the purified lysozyme $\left(1900 \mu \mathrm{g} \mathrm{ml}^{-1}\right)$ onto TSA plates that had been heavily surfaceinoculated with the viable test bacteria. The plates were then incubated at $10 \pm 2{ }^{\circ} \mathrm{C}$ for $4 \mathrm{~d}$ and examined for zones of growth inhibition.

The effect of lysozyme on the bacteria isolated from the coelomic fluid was assayed either by placing sterile $5 \mathrm{~mm}$ diameter filter paper discs saturated with egg yolk material (EY) that had been diluted $(1: 3)$ in PBS or by addition of $25 \mu \mathrm{l}$ of diluted egg yolk directly onto TSA plates that had been heavily surface-inoculated with the viable test bacteria. After a period of $48 \mathrm{~h}$ incubation at $15^{\circ} \mathrm{C}$, antibacterial activity was evident as a clear zone around the egg yolk material disc/site where the test bacteria had failed to grow.

Lysis assay: The following lysoplate method was developed to screen Aeromonas hydrophila, A. salmonicida, Carnobacterium piscicola, and Renibacterium salmoninarum for their susceptibility to lysis by coho egg lysozyme. Cells from log-phase cultures were washed twice and suspended in PBS. Each suspension was adjusted to an absorbance of 1.5 at $540 \mathrm{~nm}$ (the absorbance of Micrococcus lysodeikticus when used as a substrate in the lysoplate method). Agarose (Type 1. Sigma) was added to each suspension to a final concentration of $0.5 \%(\mathrm{w} / \mathrm{v})$ and the mixture was heated to boiling for 10 min with stirring to kill the bacteria, and to dissolve the agarose. The preparation was then poured into Petri dishes $\left(35 \times 10 \mathrm{~mm}, 5 \mathrm{ml} \mathrm{dish}{ }^{-1}\right)$, and when the agarose had set, wells were made and subsequently charged with $20 \mu \mathrm{EY}$ well ${ }^{-1}$ (lysozyme activity $=1900 \mu \mathrm{g} \mathrm{ml}^{-1}$ ). The plates were incubated in a humid chamber at room temperature for $20 \mathrm{~h}$ and examined for zones of clearing due to bacterial lysis around the wells.

\section{RESULTS AND DISCUSSION}

Lysozyme proved lethal for 3 of the 4 bacterial fish pathogens tested, the bactericidal effect being dependent on the concentration of the enzyme present (Table 2). With the lysozyme-sensitive pathogens (Aeromonas hydrophila, A. salmonicida, and Carnobacterium piscicola), a complete kill was achieved in $90 \mathrm{~min}$ or less when the enzyme concentration was $700 \mu \mathrm{g} \mathrm{ml}^{-1}$. With lower concentrations of lysozyme there was little or no bactericidal effect within the 90 min observation period. With Renibacterium salmoninarum, however, there was essentially no decrease in viability noted with any of the lysozyme concentrations tested, suggesting that the organism was refractory to the enzyme. This lack of lysozyme susceptibility held true even when, in a second experiment, $R$. salmoninarum was exposed to concentrations of lysozyme equivalent to those found in salmonid eggs

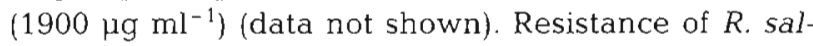
moninarum to the coho egg lysozyme was not entirely surprising as the organism was reported to resist lysis by HEWL even after incubation periods for up to $1 \mathrm{wk}$ at $37^{\circ} \mathrm{C}$ (see Fryer \& Sanders 1981 ).

Table 2. Effect of coho salmon Oncorhynchus kisutch egg lysozyme on the viability of various bacterial fish pathogens. Bacterial cell populations (colony-forming units, CFU) at the start of the experiment were: Aeromonas hydrophila $\left(5.1 \times 10^{8} \mathrm{ml}^{-1}\right)$; A. salmonicida $\left(1.6 \times 10^{9} \mathrm{ml}^{-1}\right)$; Carnobacterium piscicola $\left(1.9 \times 10^{6} \mathrm{ml}^{-1}\right)$; Renibacterium salmoninarum $\left(1.6 \times 10^{9} \mathrm{ml}{ }^{-1}\right)$. The cells were incubated in the presence or absence of lysozyme, and the results are expressed as the \% reduction in viable cells after $90 \mathrm{~min}$ incubation at room temperature $\left(20\right.$ to $22^{\circ} \mathrm{C}$ ) (mean of triplicate assays $\pm \mathrm{SD}$ )

\begin{tabular}{|cccrr|}
\hline Lysozyme $\left(\mu \mathrm{g} \mathrm{ml}^{-1}\right)$ & A. hydrophila & A. salmonicida & C. piscicola & R. salmoninarum \\
\hline 0 & $0 \pm 0.04$ & $0 \pm 0.02$ & $0 \pm 0.02$ & $0 \pm 0.06$ \\
100 & $0 \pm 0.03$ & $2.6 \pm 0.01$ & $3.4 \pm 0.04$ & $1.1 \pm 0.04$ \\
400 & $8.5 \pm 0.04$ & $9.1 \pm 0.01$ & $3.4 \pm 0.02$ & $1.1 \pm 0.02$ \\
700 & $100 \pm 0.0$ & $100 \pm 0.0$ & $100 \pm 0.0$ & $2.2 \pm 0.02$ \\
\hline
\end{tabular}


The foregoing tests with lysozyme were conducted at room temperature, a temperature not physiologically realistic for salmonid eggs (Velsen 1987). However when the tests were repeated at a temperature normally experienced by salmonid eggs with the 3 abovementioned lysozyme-sensitive fish pathogens, the antibacterial activity of the enzyme was again evident. Clear zones occurred around the lysozyme spots on the inoculated TSA plates, indicating that the enzyme was active against these pathogens even at low, physiologically realistic temperatures. In similar tests conducted at $15^{\circ} \mathrm{C}$ with the isolates obtained from the coelomic fluid of a mature coho salmon, the 2 Corynebacterium isolates proved susceptible to the lysozyme (clear zones produced) but the Flavobacterium isolate proved resistañt \{no clear zone produced\}.

Our results for Aeromonas hydrophila support the findings of Kudo \& Inoue (1986) who showed that extracts from the outer membrane of fertilized eggs of rainbow trout Oncorhynchus mykiss and Tribolodon hakonensis were lethal for this bacterium. The lysozyme susceptibility shown by this organism as well as that exhibited by A. salmonicida and Carnobacterium piscicola probably explains why these organisms are not considered, based on practical observations made over the years, to be vertically transmitted. Indeed, experiments to examine this point with $A$. salmonicida indicate that it is not vertically transmitted (Bullock \& Stuckey 1987). On the other hand, the lysozyme resistance shown by Renibacterium salmoninarum may explain why this organism survives in salmonid eggs well enough to be vertically transmitted.

Grinde et al. (1988) presented evidence for the presence of 2 distinct types of lysozyme in the kidney of rainbow trout. One of the lysozymes showed substantial antimicrobial activity (both bactericidal and bacteriolytic) against Vibrio anguillarum, Vibrio salmonicida, Aeromonas salmonicida, Yersinia ruckeri, and a Flavobacterium sp. In contrast, the coho egg lysozyme tested in the present study was bactericidal but not bacteriolytic. With the lysoplate method used in this study, none of the heat-killed lysozyme-sensitive pathogens tested showed zones of clearing around the wells containing the coho egg lysozyme. (In contrast, in tests with the reference strain Micrococcus lysodeikticus conducted under identical conditions, zones of clearing occurred around the lysozyme wells.)

The fact that some of the pathogens in our tests were killed but not lysed by the coho egg lysozyme supports the conclusion of Iacono et al. (1980) that the mechanisms underlying the bactericidal and lytic properties of the enzyme are not always the same. Hydrolysis of peptidoglycan by lysozyme is one explanation for the enzyme's antibacterial activity; however, bactericidal effects of some forms of lysozyme may depend on activities of these enzymes unrelated to an ability to hydrolyse the peptidoglycan. Lysozyme has been shown to bind to the lipopolysaccharide of Pseudomonas aeruginosa (Day et al. 1978) and other cell structures like the cytoplasmic membrane (Iacono et al. 1980). Binding of lysozyme to the tested Gramnegative fish pathogens might therefore result in damage to the outer cell membrane, thus permitting additional lysozyme to reach and injure deeper-lying structures like the cytoplasmic membrane. The latter may thus be rendered so permeable as to result in the loss of cell viability without lysis.

Sauter et al. (1987) reported the occurrence of a wide range of bacteria in the eggs of chinook salmon Oncorhynchus tshawytscha from a population of highly stressed fish. Their findings are, however, at odds with the results of others who report that the yolk of salmonid eggs and alevins, unlike the egg and alevin surfaces (Bell et al. 1969, Yoshimizu et al. 1980, Barker et al. 1989), are generally bacteria-free (Yoshimizu et al. 1980, Evelyn et al. 1984a, b, Barker et al. 1989, 1991, Lee \& Evelyn 1989). Intra-ovum infections with bacteria and viruses appear, therefore, to be rare events. If they occur, they may be transitory and therefore go undetected because of the various antimicrobial factors that apparently occur in eggs (Voss et al. 1978, Yoshimizu et al. 1980, 1989, Kudo \& Inoue 1986, 1989, Kudo et al. 1988). The findings with lysozyme in the present study clearly show that this enzyme also plays a role in determining why certain bacterial fish pathogens are unlikely to survive in, and be vertically transmitted by, salmonid eggs; the findings are also of interest because they illustrate that salmon egg lysozyme exerts its antibacterial effect by some mechanism other than bacterial lysis.

Acknowledgements. A.N.Y was in receipt of a scholarship from the government of the Sudan. The authors thank L. Needham for reading the manuscript and L. Prosperi-Porta for technical assistance. This research was partially supported by a Natural Sciences and Engineering Research Council of Canada operating grant to L.J.A.

\section{LITERATURE CITED}

Austin, B., Embley, T M., Goodfellow, M. (1983). Selective isolation of Renibacterium salmoninarum. FEMS Microbiol. Lett. 17: 111-114

Barker, G. A., Smith, S. N., Bromage, N. R. (1989). The bacterial flora of rainbow trout, Salmo gairdneri Richardson, and brown trout, Salmo trutta L., eggs and its relationship to developmental success. J. Fish Dis. 12. 281-293

Barker, G. A., Smith, S. N., Bromage, N. R. (1991). Commensal bacteria and their possible relationship to the mortality of incubating salmonid eggs. J. Fish Dis. 14: 199-210

Bell, G. R., Hoskins, G. E., Bagshaw, J. W. (1969). On the structure and enzymatic degradation of the external membrane of the salmon egg. Can. J. Zool. 47: 146-148 
Bullock, G. L., Stuckey, H. M. (1987). Studies on vertical transmission of Aeromonas salmonicida. Prog. Fish Cult. 49: 302-303

Collins, M. D., Farrow, J A. E., Philips, B. A., Ferusu, S., Jones, D. (1990). Classification of Lactobacillus divergens, Lactobacillus piscicola, and some catalase-negative, asporogenous, rod-shaped bacteria from poultry in a new genus, Carnobacterium. Int. J. syst. Bacteriol. 37: 310-316

Cone, D. K. (1982). A Lactobacillus sp. from diseased female rainbow trout, Salmo gairdneri Richardson, in Newfoundland, Canada. J. Fish Dis. 5: 479-485

Daly, J. G., Stevenson, R. M. W. (1985). Charcoal agar, a new growth medium for the fish disease bacterium Renibacterium salmoninarum. Appl. environ. Microbiol. 50: $868-871$

Day, D. F., Marceau-Day, M. L., Ingram, J. M. (1978). Proteinlipopolysaccharide interactions. I. The reaction of lysozyme with Pseudomonas aeruginosa LPS. Can. J. Microbiol. 24: 196-199

Evelyn, T. P. T. (1977). An improved growth medium for the kidney disease bacterium and some notes on using the medium. Bull. Off. int. Epizoot. 87: 511-513

Evelyn, T. P. T., Bell, G. R., Prosperi-Porta, L., Ketcheson, J. E. (1989). A simple technique for accelerating the growth of the kidney disease bacterium Renibacterium salmoninarum on a commonly used culture medium (KDM2). Dis. aquat. Org. 7: 231-234

Evelyn, T. P. T., Ketcheson, J. E., Prosperi-Porta, L. (1984a). Further evidence for the presence of Renibacterium salmoninarum in salmonid eggs and for the failure of povidone-iodine to reduce the intra-ovum infection rate in water-hardened eggs. J. Fish Dis. 7: 173-182

Evelyn, T. P. T., Prosperi-Porta, L., Ketcheson, J. E. (1984b). The salmonid egg as a vector of the kidney disease bacterium, Renibacterium salmoninarum. In: ACUIGRUP (ed.) Fish Diseases, 4th COPRAQ Session. Editora ATP, Madrid, p. 111-117

Fletcher, T. C. (1982). Non-specific defence mechanisms of fish. Dev. comp. Immunol. 2: 123-132

Fryer, J. L., Sanders, J. E. (1981). Bacterial kidney disease of salmonid fish. A. Rev. Microbiol. 35: 273-298

Grinde, B. (1989). Lysozyme from rainbow trout (Salmo gairdneri) as an antibacterial agent against fish pathogens. J. Fish Dis. 12: 95-104

Grinde, B., Jolles, J., Jolles, P. (1988). Purification and characterization of two lysozymes from rainbow trout (Salmo gairdneri). Euro. J. Biochem. 173: 269-273

Hiu, S. F., Holt, R. A., Sriranganathan, N., Seidler, R. J., Fryer, J. L. (1984). Lactobacillus piscicola, a new species from salmonid fish. Int. J. syst. Bacteriol. 34: 393-400

Iacono, V. J., Mackay, B. J., DiRienzo, S., Pollock, J. J. (1980). Selective antibacterial properties of lysozyme for oral

Editorial responsibility: Managing Editor microorganisms. Infection Immunity 29: 623-632

Ingram, G. A. (1980). Substances involved in the natural resistance of fish to infection - a review. J. Fish Biol. 16 $23-60$

Krieg, R. R., Holt, J. G. (eds.) (1984). Bergey's manual of systematic bacteriology, Vol. 1. Williams and Wilkins, Baltimore

Kudo, S., Inoue, M. (1986). A bactericidal effect of fertilization envelope extract from fish eggs. Zool. Sci. 3: 323-329

Kudo, S., Inoue, M. (1989). Bactericidal action of fertilization envelope extract from eggs of the fish Cyprinus carpio and Plecoglossus altivelis. J. exp. Zool. 250: 219-228

Kudo, S., Sato, A., Inoue, M. (1988). Chorionic peroxidase activity in the eggs of the fish Tribolodon hakonensis J. exp. Zool. 245: 63-70

Lee, E. G.-H., Evelyn, T. P. T. (1989). Effect of Renibacterium salmoninarum levels in the ovarian fluid of spawning chinook salmon on the prevalence of the pathogen in their eggs and progeny. Dis. aquat. Org. 7: 179-184

Lie, Ø., Evensen, Ø., Sorensen, A., Froysadal, E. (1989). Study on lysozyme activity in some fish species. Dis. aquat. Org. 6: $1-5$

Lindsay, G. J. H. (1986). The significance of chitinolytic enzymes and lysozyme in rainbow trout Salmo gairdneri defence. Aquaculture 51: 169-173

McHenery, J. G., Birkbeck, T. H., Allen, J A. (1979). The occurrence of lysozyme in marine bivalves. Comp. Biochem. Physiol. 63B: 25-28

Sauter, R. W., Williams, C., Meyer, E. A., Celnik, B., Banks, J. L., Leith, D. A. (1987). A study of bacteria present within unfertilized salmon eggs at the time of spawning and their possible relation to early lifestage disease. J. Fish Dis. 10: $193-203$

Sneath, P. H. A., Mair, N. S., Sharpe, M. E., Holt, J. G. (eds.) (1986). Bergey's manual of systematic bacteriology, Vol. 2. Williams and Wilkins, Baltimore

Velsen, F. P. J. (1987). Temperature and incubation in Pacific salmon and rainbow trout: compilation of data on median hatching time, mortality, and embryonic staging. Data Rep. Can. Fish. Aquat. Sci. 626: 1-58

Voss, E. W., Fryer, J. L., Banowetz, G. M. (1978). Isolation, purification, and partial characterization of a lectin from chinook salmon ova. Arch. Biochem. Biophys. 186: 25-34

Yoshimizu, M., Kimura, T., Sakai, M. (1980). Microflora of the embryo and the fry of salmonids. Bull. Jap. Soc. Sci. Fish. 46: $967-975$

Yoshimizu, M., Sami, M., Kimura, T. (1989). Survivability of infectious hematopoietic necrosis virus in fertilized eggs of masu and chum salmon. J. aquat. Anim. Health 1: 13-20

Yousif, A. N., Albright, L. J., Evelyn, T. P. T. (1991). Occurrence of lysozyme in the eggs of coho salmon Oncorhynchus kisutch. Dis. aquat. Org. 10:45--49

Manuscript first received: August 26, 1993

Revised version accepted: March 15, 1994 